Original article

\title{
Evaluation of the infection process by Lecanicillium fungicola in Agaricus bisporus by scanning electron microscopy
}

\author{
Janaira Santana Nunes ${ }^{a}$, Manuela Rocha de Brito ${ }^{a}$, Diego Cunha Zied ${ }^{\mathrm{b}}$, \\ Eloisa Aparecida das Graças Leite ${ }^{\mathrm{a}}$, Eustáquio Souza Dias ${ }^{\mathrm{a}}$, Eduardo Alves ${ }^{\mathrm{a}, *}$ \\ a Universidade Federal de Lavras, 37200-000 Lavras, MG, Brazil \\ b Universidade Estadual Paulista (UNESP), Faculdade de Ciências Agrárias e Tecnológicas, Câmpus de Dracena, 17900-000 Dracena, SP, Brazil
}

\section{A R T I C L E I N F O}

\section{Article history:}

Received 11 September 2015

Accepted 29 April 2016

Available online 3 February 2017

\section{Keywords:}

Scanning electron microscopy

Mushroom

X-ray microanalyses

Mycopathogen

\begin{abstract}
A B S T R A C T
Background: Lecanicillium fungicola causes dry bubble disease in Agaricus bisporus mushrooms leading to significant economic losses in commercial production.

Aims: To monitor the infection process of L. fungicola in Brazilian strains of A. bisporus.

Methods: The interaction between the mycelium of L. fungicola (LF.1) and three strains of $A$. bisporus (ABI 7, ABI 11/14 and ABI 11/21) was studied. Electron microscopy and X-ray microanalyses of vegetative growth and basidiocarp infection were evaluated.

Results: Micrographs show that the vegetative mycelium of the Brazilian strains of A. bisporus is not infected by the parasite. The images show that the pathogen can interlace the hyphae of $A$. bisporus without causing damage, which contributes to the presence of $L$. fungicola during the substrate colonization, allowing their presence during primordial formation of $A$. bisporus. In the basidiocarp, germ tubes form within $16 \mathrm{~h}$ of infection with $L$. fungicola and the beginning of penetration takes place within $18 \mathrm{~h}$, both without the formation of specialized structures.

Conclusions: Scanning electron microscopy enabled the process of colonization and reproduction to be observed within the formation of phialides, conidiophores and verticils of L. fungicola. The formation of calcium oxalate crystals by the pathogen was also visible using the X-ray microanalysis, both at the hyphae in the Petri plate and at basidiocarp infection site.
\end{abstract}

@ 2016 Asociación Española de Micología. Published by Elsevier España, S.L.U. All rights reserved.

\section{Evaluación del proceso de infección por Lecanicillium fungicola en Agaricus bisporus por microscopia electrónica de barrido}

\section{R E S U M E N}

Antecedentes: Lecanicillium fungicola es el agente causal de la enfermedad de la mole seca en Agaricus bisporus, responsable de importantes pérdidas económicas en la producción comercial de esta seta. Objetivos: Comprobar el proceso de infección de L. fungicola en cepas brasileñas de A. bisporus.

Métodos: Se estudió la interacción entre el micelio de L. fungicola (LF.1) y tres cepas de A. bisporus (ABI 7, ABI 11/14 y ABI 11/21). Se evaluaron mediante microscopia electrónica y microanálisis de rayos $\mathrm{X}$ el crecimiento vegetativo y la infección de los basidiocarpos.

Resultados: Las micrografías muestran que el micelio vegetativo de las cepas brasileñas de $A$. bisporus no resultó afectado por la infección del parásito. Las imágenes muestran también cómo el agente patógeno puede entrelazar las hifas de A. bisporus sin causar daños, lo que contribuye a la perpetuación de L. fungicola durante la colonización del sustrato y durante la formación de los primordios de A. bisporus. En el basidiocarpo, los tubos germinales se forman después de $16 \mathrm{~h}$ de la infección con L. fungicola y el comienzo de la penetración tiene lugar tras 18 h, sin formación de estructuras especializadas.

\footnotetext{
* Corresponding author.

E-mail address: ealves@dfp.ufla.br (E. Alves).
} 
Conclusiones: La microscopia electrónica permite observar el proceso de colonización y reproducción con la formación de fiálides, conidióforos y verticilos de L. fungicola. La formación de cristales de oxalato de calcio por parte del agente patógeno también fue visible mediante el microanálisis por rayos $\mathrm{X}$, tanto en la infección de las hifas en placa de Petri como en la de los basidiocarpos.

(C) 2016 Asociación Española de Micología. Publicado por Elsevier España, S.L.U. Todos los derechos reservados.

Lecanicillium fungicola (Preuss) Zare and Gams [synonyms: Verticillium fungicola (Preuss) Hassebrauk, Verticillium malthousei (Preuss) Ware] is the etiological agent of the disease known as dry bubble (Zare and Gams ${ }^{24}$ ) in commercial mushroom (Agaricus bisporus) production, and contributes to major economic losses. ${ }^{1}$ Symptoms vary from small brown necrotic lesions on the basidiocarp to stem peeling/bending or splitting of the stipe, and shapeless and undifferentiated non-necrotic masses in the mushroom tissue. ${ }^{14}$ Control of the disease depends on exhaustive sanitation and hygiene and on the use of fungicides. Fungicide resistance is common. ${ }^{10,18}$

L. fungicola infection seems to occur first by adhesion of hydrophobins present in the wall of both fungi. After the initial connection, the fungus can grow inter- and intracellularly, due to weakening of the cell wall of $A$. bisporus by the action of lytic enzymes and mechanical pressure of the pathogen. ${ }^{6}$ The infection occurs when the mushrooms develop mature sporocarps prior to or after harvest. ${ }^{15}$ Observation of them suggests that the vegetative mycelium is not affected. Some microscopic and biochemical studies have been published to clarify the process of infection, but this is not fully elucidated. ${ }^{2,6,24}$

There is some variability in relation to virulence between groups of L. fungicola. ${ }^{12}$ Two varieties of L. fungicola affect cultures of A. bisporus: the aleophilum variety, which affects mushroom culture in Canada and in the USA, ${ }^{7}$ and the fungicola variety, responsible for the disease in Britain, the Netherlands, Spain and France. ${ }^{12}$ In Brazil, the variety that affects the production of $A$. bisporus has not been identified.

The L. fungicola infection process has been analyzed by biochemical and molecular methods., ${ }^{75}$ However, its visualization is only possible through morphological studies. Scanning electron microscopy has been an important tool in studies related to the pathogen/host interaction, i.e. adhesion, germination, penetration, colonization and reproduction of pathogens. ${ }^{4}$ In addition, morphological studies are prerequisites in the development of control strategies.

This study was conducted in order to monitor the infection process of $L$. fungicola in three strains of $A$. bisporus, both in the vegetative phase and at the stage of basidiocarps, by scanning electron microscopy.

\section{Material and methods}

\section{Hyphal interaction}

To study the interaction along the vegetative stage, mycelia of L. fungicola (LF.1) and three strains of A. bisporus (ABI 7, ABI 11/14 and ABI 11/21) from the mycology collection of the Edible Mushrooms Laboratory at the Federal University of Lavras (UFLA) were used. The strains used were maintained in subcultures (Potato Dextrose Agar - PDA; Difco, Lawrence, USA), and were isolated directly from the basidioma, according to Zied et al. ${ }^{25}$ The L. fungicola strain was isolated from diseased mushrooms collected by growers in the city of Mogi das Cruzes, Sao Paulo State (Brazil). The strains of A. bisporus are described in the manuscript presented by Zied et al. ${ }^{26}$
Discs $(0.5 \mathrm{~cm}$ in diam.) containing inoculum of the fungi ( $A$. bisporus strains and L. fungicola) were transferred to a Petri dish ( $8 \mathrm{~cm}$ in diameter) with PDA on opposite sides and maintained at $25 \pm 0.5^{\circ} \mathrm{C}$ in a controlled chamber. Due to the difference in the growth rate of the two fungi strains, $A$. bisporus was inoculated 10 days before $L$. fungicola. Five $1 \mathrm{~cm}^{2}$ samples were taken at the interface of the colonies on days 1, 3, 5 and 10 . The collection time was determined from tests developed previously by the authors.

\section{Cultivation of mushrooms and inoculation of $\mathrm{L}$. fungicola}

For the infection studies of L. fungicola in mushrooms the same strains described aforementioned were used. Commercially prepared, pasteurized and conditioned compost was obtained from "Sítio dos Micélios" (Barbacena, MG, Brazil) and inoculated with the strains of $A$. bisporus and maintained at $25 \pm 1{ }^{\circ} \mathrm{C}$ for 20 days, until the total colonization of the substrate. In order to induce basidiocarps formation, a casing layer containing dystrophic red latosol (Oxisol) and coal, in the ratio 1:2, and calcitic limestone (5\%) was used. After the addition of the casing layer, the substrates were incubated at $20 \pm 1{ }^{\circ} \mathrm{C}$ and $90 \%$ humidity in mushroom-growing rooms (Universidade Federal de Lavras), following the methodology presented by Pardo-Giménez et al. ${ }^{20}$ After the onset of the primordium (mushrooms with a diam. of approximately $2.5 \mathrm{~cm}$ ), $5 \mu \mathrm{l}$ of a L. fungicola $\left(1 \times 10^{4} \mathrm{ml}^{-1}\right)$ spore suspension were inoculated at different points $(0.5 \mathrm{~cm}$ apart $)$ on the surface of the pileus. The spore suspension was obtained by adding distilled and autoclaved water into a pure culture of the pathogen, and then rubbing was carried out with a Drigalsky handle, following the methodology described by Zied et al. ${ }^{26}$ Five $1 \mathrm{~cm}^{2}$ samples of the infected mushrooms were taken at $12,14,16,18,20,30,40,50,70$ and $140 \mathrm{~h}$. The collection time was determined from previous tests presented by Zied et al. ${ }^{26}$ For each time interval, 30 mushrooms were used, and five samples were taken from each one, making a total of 150 samples.

\section{Scanning electron microscopy}

All collected samples were pre-fixed in modified Karnovsky fixer (2.5\% glutaraldehyde, $2.5 \%$ formaldehyde in $0.05 \mathrm{M}$ phosphate buffer, pH 7.2) for a period of, at least, $24 \mathrm{~h}$ at $4{ }^{\circ} \mathrm{C}$. Some mushroom samples infected with the pathogen were removed from the pre-fixative and transferred to $30 \%$ glycerol for $30 \mathrm{~min}$; then the samples were immersed in liquid nitrogen and fractured with a scalpel on a metal plate. After fixation, the standard protocol for scanning electron microscopy described by Bozzola and Russell, ${ }^{3}$ with modifications, was used.

Samples were washed three times in $0.05 \mathrm{M}$ phosphate buffer for $10 \mathrm{~min}$ each, and dehydrated in acetone gradient (25\%, 50\%, $75 \%$ and $90 \%$, and three times $100 \%$ ). After dehydration, samples were taken to a Balzers CPD 030 critical point dryer device to replace acetone with $\mathrm{CO}_{2}$ and to complement drying. Specimens were mounted on aluminum brackets (stubs) with carbon tape on aluminum foil paper, covered with gold in a Balzers SCD 050 evaporator and then observed in a LEO EVO 40 XVP scanning electron 
microscope. Crystals were observed in samples where the pileus surface was infected by the pathogen spore suspension. Therefore, it was possible to qualify/quantify their chemical composition by Energy Dispersive X-ray Spectrometry using a QUANTAX XFlash Bruker 5010 device coupled with an electron scanning microscope. Thus, samples pre-fixed in Karnovisky were newly prepared according to the transmission electron microscopy standard protocol mentioned above with a single modification. The specimens were covered with a carbon evaporator device, model Balzer CED 020 , mounted on aluminum brackets (stubs) and then observed in a LEO EVO 40 XVP device.

\section{Results}

\section{Hyphal interaction between pathogen/host}

Micrographs obtained by scanning electron microscope show the interaction between the hyphae of A. bisporus and the L. fungicola strain (Fig. 1). After contact with the pathogen, the hyphae of A. bisporus showed no degradation of the cell wall or penetration symptoms in any of the A. bisporus strains analyzed. Our images showed that the vegetative mycelium of the Brazilian A. bisporus strains is not affected by the infection with $L$. fungicola. The electron micrographs also show that the vegetative mycelium of $A$. bisporus does not change its morphological structure. On the other hand, we observed that spores and hyphae of $L$. fungicola adhered to the surface of the host (Fig. 1C and D) and coiled hyphae (Fig. 1B) around the hypha host.

\section{First steps in L. fungicola infection}

There were no differences in the infection process of $L$. fungicola on the three strains of $A$. bisporus. The onset of germination occurred $16 \mathrm{~h}$ after inoculation, when the conidia issued 1,2 or 3 germ tubes, with unilateral predominance (Fig. $2 \mathrm{~A}-\mathrm{G}$ ). The germ tubes were issued at the ends of the pathogen conidia; however, there were some which came sideways.

After $18 \mathrm{~h}$, it was possible to visualize the penetration of $L$. fungicola in the mushroom tissue (Fig. $2 \mathrm{C}-\mathrm{G}$ ). There was no formation of specialized penetration structures in our samples. L. fungicola started colonization of the mushroom tissue after penetration. Forty hours after the inoculation, we observed the formation of characteristic conidiophores, phialides and verticils of $L$. fungicola (Fig. $2 \mathrm{H}-\mathrm{I}$ ). The conidiophores were erect with 3 to 5 spiral phialides. We observed a higher degree of infection $50 \mathrm{~h}$ after inoculation when compared to $18 \mathrm{~h}$ after inoculation (Fig. 3A-B). The expression of symptoms (dark spots on the tissue) was observed $72 \mathrm{~h}$ after inoculation. The cross-sectional analysis of the infected tissue samples allowed us to observe the production of conidia and hyphal colonization in more inner parts of the basidiocarp (Fig. 4A-C).

The presence of calcium crystals was observed both in the culture medium, where there was an interaction with hyphae, and in the mushroom-infected tissue (Figs. 1A, C and 5A). Using X-ray microanalysis (EDS), the crystal element is composed of calcium (Fig. 5B) and oxygen (Fig. 5B and D), confirming that it is calcium oxalate. By cultivating the two fungi separately, we observed the presence of crystals only in the L. fungicola culture.

\section{Discussion}

Using scanning electron micrographs, it is possible to observe the interaction between hyphae from $A$. bisporus and L. fungicola lineages, since the $L$. fungicola hyphae are distinct from the $A$. bisporus ones due to their smaller diameter. ${ }^{5}$ Our images confirm that the vegetative mycelium of $A$. bisporus is resistant to the infection of L. fungicola. The same was observed by Shamshad et al. ${ }^{22}$ while studying the interaction between the vegetative mycelia of A. bisporus and L. fungicola, demonstrating through transmission electron microscopy that there was no infection.
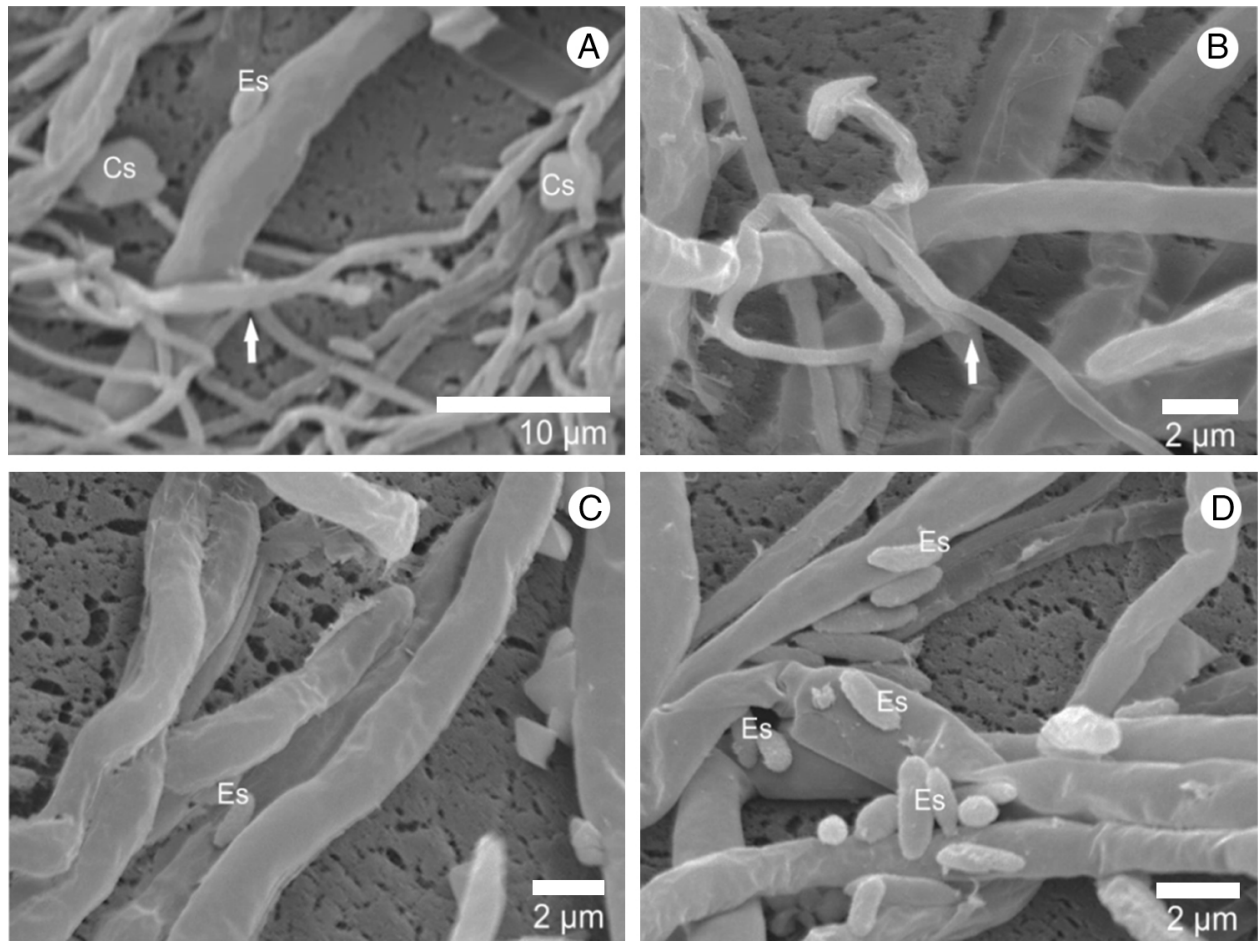

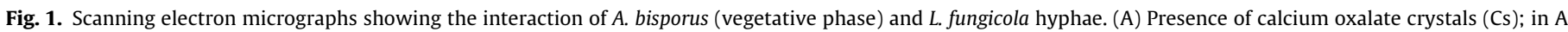
and B arrows indicate the L. fungicola hyphae; in (A, C and D): adhesion of spores (Es) on A. bisporus hyphae. 

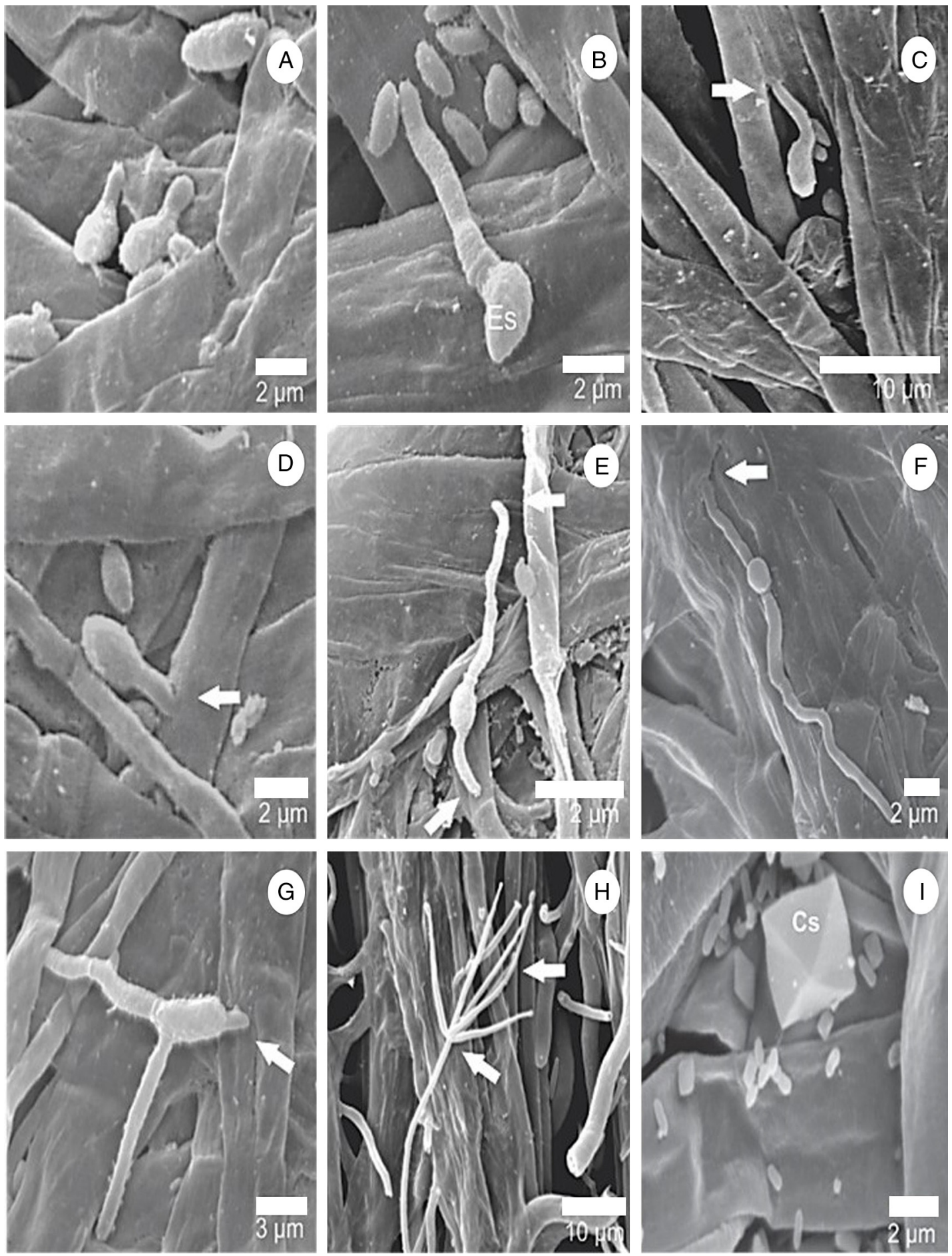

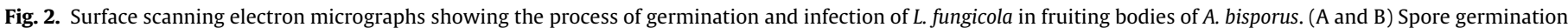

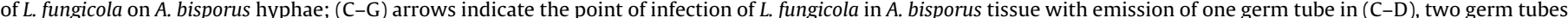
in (E-F) and three germ tubes in G; (H) formation of $L$. fungicola conidiophores whorls and phialides in verticils; (I) presence of calcium oxalate crystals (Cs).

On the other hand, spores and hyphae of L. fungicola are either attached to the surface or rolled around the vegetative hyphae of the host. Probably this behavior helps the pathogen to be in the period of colonization of the substrate by A. bisporus (spawn run), allowing it to be present at the beginning of the formation of primordia. When infection occurs at the beginning of the fruiting body formation (formation of the button), the fruiting body does not develop, causing a mass of undifferentiated tissue of the stem and pileus, forming a shapeless mass giving rise to the disease named dry bubble. In this case, the disease is more aggressive, causing major losses of production. ${ }^{1}$

It is likely that the pathogen can adhere to the host by means of hydrophobic interactions between the layers of hydrophobin. In A. bisporus, the outer surface of the vegetative hypha is covered by ABH3-type hydrophobins. ${ }^{16}$ In L. fungicola, amino acid composition analysis showed the presence of class II hydrophobins. ${ }^{6}$ Even with the apparent adhesion between A. bisporus and L. fungicola, the penetration of the pathogen in vegetative hyphae of $A$. bisporus 

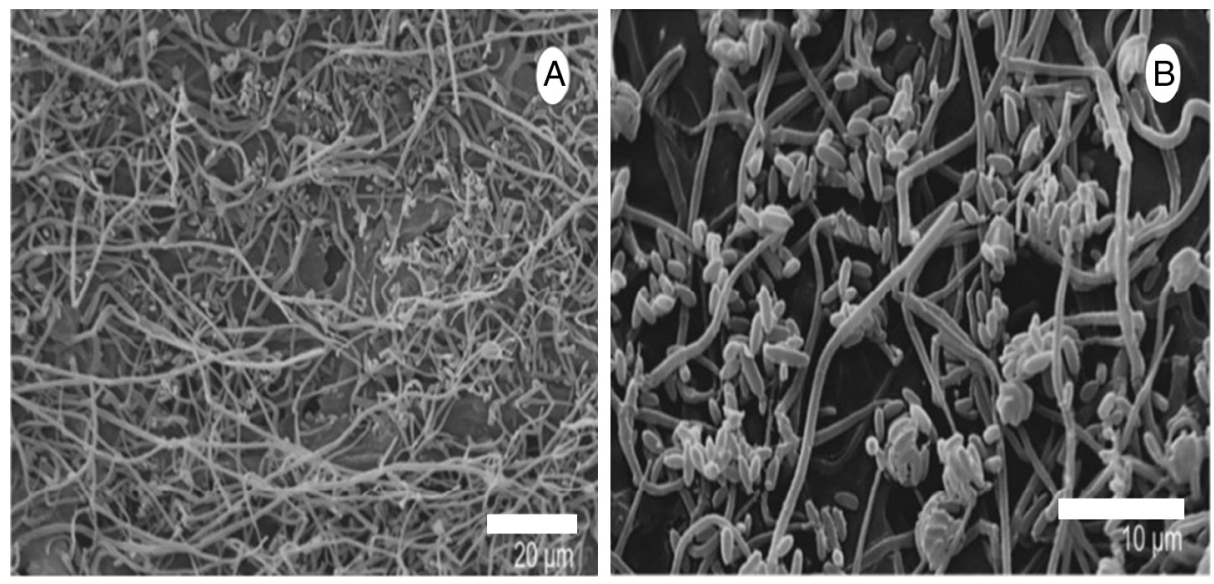

Fig. 3. Surface scanning electron micrographs of $A$. bisporus mushrooms $50 \mathrm{~h}$ after inoculation with $L$. fungicola. (A and B) show all the tissue colonized by the pathogen.

strains was not seen in electron micrographs. Therefore, even if the penetration process does not occur, an interaction mediated by hydrophobins is considered to be important, since it allows the presence of the pathogen at the time of the primordial initiation. ${ }^{5}$

L. fungicola appears to have a lytic effect on the vegetative mycelium wall of $A$. bisporus, suggesting that the infection process depends on the chemical composition and structure of the cell wall of the host. ${ }^{5}$ Bernardo et al. ${ }^{2}$ confirmed this hypothesis, noting that the cell wall of the parasite has glicogalactomannans that are able to recognize and bind to the lectin present in the fruiting body of the host. The vegetative mycelium of $A$. bisporus does not contain lectin in its composition, only the fruit body does. ${ }^{6}$

Perez Cabo and Garcia Mendoza ${ }^{21}$ found similar effects of glicogalactomannans of $L$. fungicola in haemagglutination activity in a lectin of Pleurotus ostreatus. This implies that this mechanism can work in other susceptible species. However, new evidence on the need for the lectin in the process should be explored.

To the best of our knowledge, the pathogen infection process occurs in the fruiting body hyphae rather than in the vegetative hyphae. ${ }^{19,22}$ Our results highlight the first one reported regarding the study of the disease development over time comprising 16-50 h after inoculation. During this period, it was possible to visualize from the germination to the penetration of the pathogen in the host and the most usual symptom, which is the dry bubble often followed by browning.

The latent tyrosinase present in the tissues of mushrooms can be activated after a cell leakage caused by infection. The activation of the enzyme may end in melanin synthesis. ${ }^{23}$ Largeteau et al. ${ }^{13}$ analyzed the tissues of $A$. bisporus with dark spots and showed that the darkening was not an effective defense mechanism, but indicated a high level of infection, leading to change in the tissue. Based on the literature and on the data, necrosis occurs when the mushroom biomass is significantly affected.

The pathogen grows preferentially intercellularly, but is also able to penetrate the cell walls of the hyphae fruiting body. ${ }^{8}$ The observation of the inner hyphal colonization was most evident after the mushroom tissue injury. It is believed, based on the data, that the injuries facilitate the penetration of the basidiocarp, and since the infectious process has been established, the pathogen can finally infect the inside of the hyphae.

In our study, the presence of calcium oxalate crystals was visualized during the interaction of the vegetative hyphae as well as after a high level of $L$. fungicola infection. By cultivating the two fungi separately, we observed the presence of crystals only in L. fungicola. This allowed us to infer that the crystals had been produced as a part of the pathogen metabolism. Possibly, such crystals were found previously by Zare and Gams ${ }^{24}$ for L. fungicola while observing the production of octahedral crystals in the culture medium, even though they did not investigate their composition.

Masaphy et al. ${ }^{17}$ verified the presence of calcium oxalate in $A$. bisporus cultivation and mentioned that these forms are due to the oxalic acid produced by the mushroom, which reacts with the calcium carbonate in the casing layer. The authors emphasize that the formation of these crystals is harmful to mushroom production and there are certain bacteria in the casing layer capable of degrading them for subsequent mushroom formation.
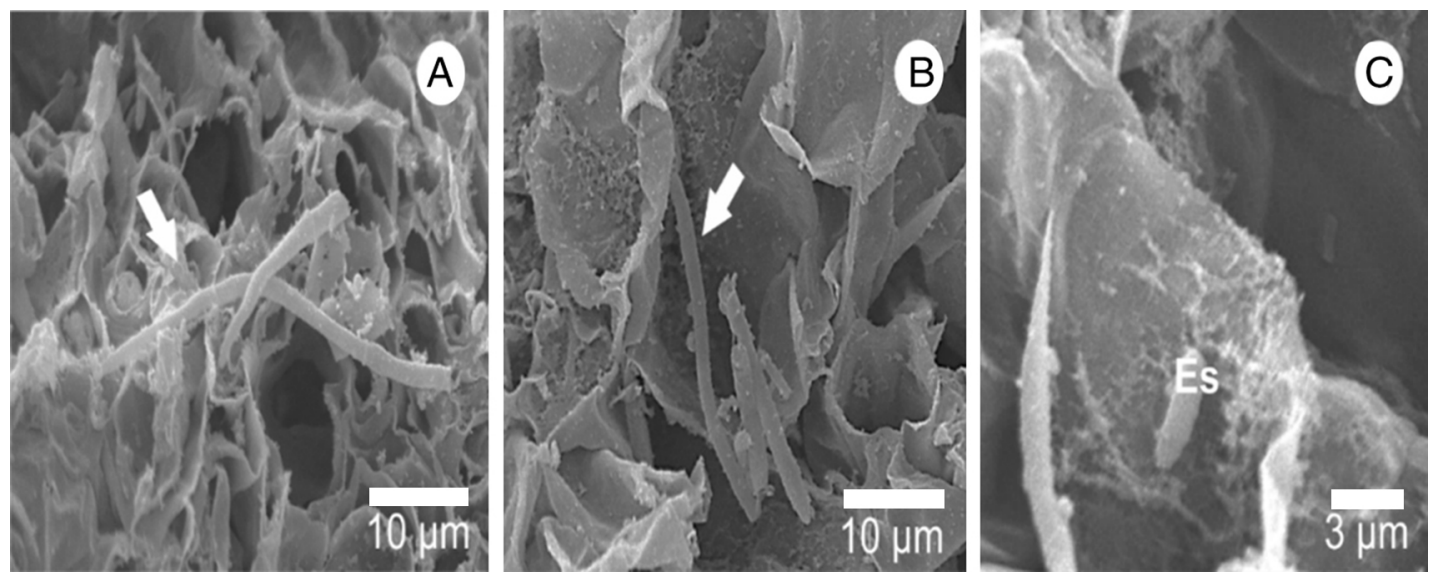

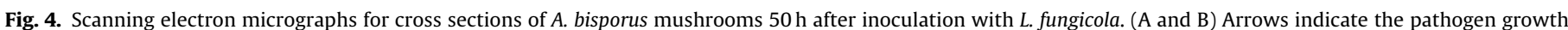
within the host hyphae of $A$. bisporus; (C) spore (Es) adhered to the interior of the hyphae of $A$. bisporus. 

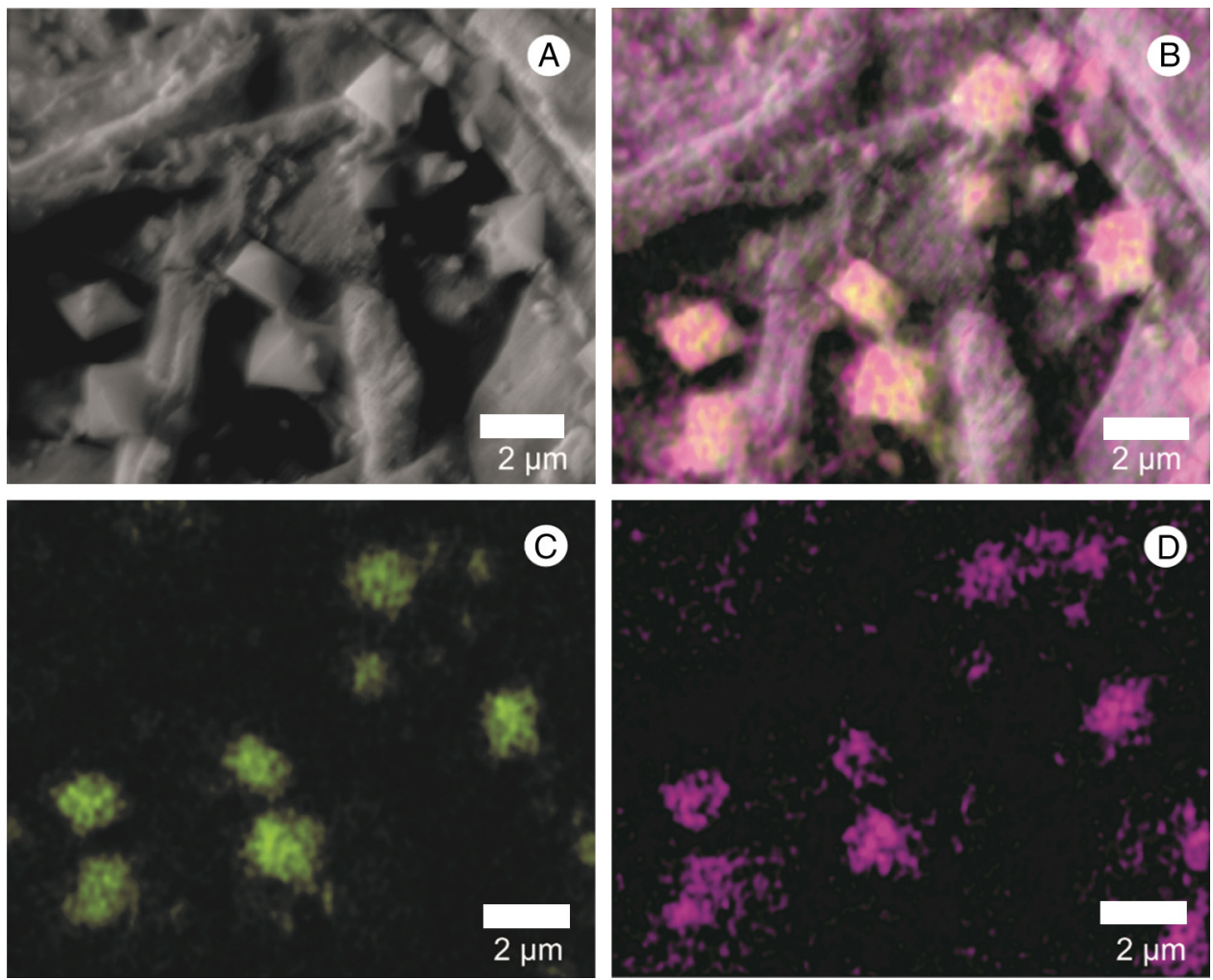

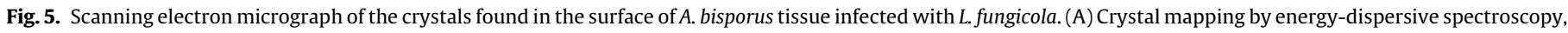

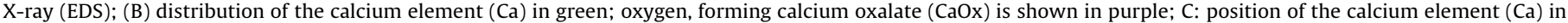
green; D: position of oxygen in purple.

Dutton and Evans ${ }^{9}$ observed that the oxalate production may contribute to the pathogenicity of fungi due to poisoning of the host cell, tissue acidification and calcium binding of the host cell wall. For some fungi, such as Sclerotinia sclerotiorum, the oxalate is an essential element for its virulence. ${ }^{11} \mathrm{New}$ studies with $L$. fungicola mutants deficient in calcium oxalate biosynthesis should be conducted in order to verify its role in the pathogenicity.

The observations have brought the evidence that the vegetative mycelia of the strains ABI 7, ABI 11/20 and ABI 11/14 are not infected by $L$. fungicola, but allows an interaction with the pathogen hyphae sufficient for the host mycelium load pathogen structures during the colonization process of the substrate. As for the formation of calcium oxalate crystals, further studies should be conducted to elucidate the formation of these crystals in the infection process.

\section{Conflict of interest}

The authors report no conflict of interest.

\section{Acknowledgements}

The authors gratefully acknowledge the Research Support Foundation of Minas Gerais (FAPEMIG), the National Council for the Improvement of Higher Education (CAPES) and the National Council for Research and Development (CNPq) for their financial support.

\section{References}

1. Berendsen RL, Baars JP, Kalkhove SIC, Lugones LG, Wösten HAB, Bakker PAH. Pathogen profile Lecanicillium fungicola: causal agent of dry bubble disease in white-button mushroom. Mol Plant Pathol. 2010;11:585-95.

2. Bernardo D, Cabo AP, Novaes-Ledieu M, Mendoza GC. Verticillium disease or 'dry bubble' of cultivated mushrooms: the Agaricus bisporus lectin recognizes and binds the Verticillium fungicola cell wall glucogalactomannan. Can J Microbiol. 2004;50:729-35.
3. Bozzola JJ, Russell LD. Electron microscopy: principles and techniques for biologists. 2nd ed. Sudbury, MA: Jones \& Bartlett; 1998.

4. Calonje M, Bernardo D, Novaes Ledieu M, Mendoza CG. Properties of a hydrophobin isolated from the mycoparasitic fungus Verticillium fungicola. Can J Microbiol. 2002;48:1030-4.

5. Calonje M, Mendoza CG, Pérez Cabo A, Bernardo D, Novaes Ledieu M. Interaction between the mycoparasite Verticillium fungicola and the vegetative mycelial phase of Agaricus bisporus. Mycol Res. 2000;104:988-92.

6. Calonje M, Mendoza CG, Galan B, Novaes-Ledieu M. Enzymic activity of the mycoparasite Verticillium fungicola on Agaricus bisporus fruit body cell walls. Microbiology. 1997;143:2999-3006.

7. Collopy PD, Amey RC, Sergeant MJ, Challen MP, Mill SPR, Foster GD, et al. The pmk1-like MAP kinase from Lecanicillium (Verticillium) fungicola is not required for virulence on Agaricus bisporus. Microbiology. 2010;156:1439-47.

8. Dragt JW, Geels FP, De Bruijn WC, Van Griensven LJLD. Intracellular infection of the cultivated mushroom Agaricus bisporus by the mycoparasite Verticillium fungicola var. fungicola. Mycol Res. 1996;100:1082-6.

9. Dutton MV, Evans CS. Oxalate production by fungi: its role in pathogenicity and ecology in the soil environment. Can J Microbiol. 1996;42:881-95.

10. Gea FJ, Navarro MJ, Tello JC. Reduced sensitivity of the mushroom pathogen Verticillium fungicola to prochloraz-manganese, in vitro. Mycol Res. 2005;109:741-5.

11. Godoy G, Steadman JR, Dickman Mb Dam R. Use of mutants to demonstrate the role of oxalic acid in pathogenicity of Sclerotinia sclerotiorum on Phaseolus vulgaris. Physiol Mol Plant Pathol. 1990;37:179-91.

12. Largeteau ML, Baars JPP, Regnault-Roger C, Savoie JM. Molecular and physiological diversity among Verticillium fungicola var. fungicola. Mycol Res. 2006;110:431-40.

13. Largeteau ML, Regnault-Roger C, Savoie JM. Verticillium disease of Agaricus bisporus: variations in host contribution to total fungal DNA in relation to symptom heterogeneity. Eur J Plant Pathol. 2007;118:155-64.

14. Largeteau ML, Savoie JM. Effect of the fungal pathogen Verticillium fungicola on fruiting initiation of its host Agaricus bisporus. Mycol Res. 2008;112: $825-8$.

15. Largeteau ML, Savoie JM. Microbially induced diseases of Agaricus bisporus: biochemical mechanisms and impact on commercial mushroom production. Appl Microbiol Biotechnol. 2010;86:63-73.

16. Lugones LG, Wösten HAB, Wessels JGH. A hydrophobin (ABH3) specifically secreted by vegetatively growing hyphae of Agaricus bisporus (common white button mushroom). Microbiology. 1998;144:2345-53.

17. Masaphy S, Levanon D, Tchelet R, Henis Y. Scanning electron microscope studies of interactions between Agaricus bisporus (Lang) Sing Hyphae and bacteria in casing soil. Appl Environ Microbiol. 1987;53:1132-7. 
18. Mehrparvar ME, Mohammadi Goltapeh E, Safaei N. Resistance of Iranian Lecanicillium fungicola to benzimidazole and ergosterol demethylation inhibiting fungicides. J Agric Sci Technol. 2013;15:389-95.

19. North LH, Wuest P. The infection process and symptom expression of Verticillium disease of Agaricus bisporus. Can J Plant Pathol. 1993;15:74-80.

20. Pardo-Giménez A, Zied DC, Alvarez MO, Rubio M, Pardo-Gonzalez JE. Effect of supplementing compost with grapeseed meal on Agaricus bisporus production. J Sci Food Agric. 2012;92:1665-71.

21. Perez Cabo A, Garcia Mendoza C. Common mechanism of recognition and binding of the complementary molecules, carbohydrate-lectin in the Verticillium disease of Agaricus bisporus and Pleurotus ostreatus cultivated mushrooms. Anal Real Acad Nac Farm. 2008;74:379-86.

22. Shamshad A, Clifta AD, Mansfield S. Host-parasite interaction between cultivated mushroom, Agaricus bisporus hybrid strain Sylvan A15, and the mycoparasite Verticillium fungicola, a causal agent of dry bubble disease. Australas Plant Pathol. 2009;38:74-8.

23. Soler-Rivas C, Jolivet S, Arpin N, Olivier JM, Wichers HJ. Biochemical and physiological aspects of brown blotch disease of Agaricus bisporus. FEMS Microbiol Rev. 1999;23:591-614

24. Zare R, Gams W. A revision of the Verticillium fungicola species complex and its affinity with the genus Lecanicillium. Mycol Res. 2008;112:811-24.

25. Zied DC, Minhoni MTA, Kopytowski Filho J, Andrade MCN. Production of Agaricus blazei ss. Heinemann (A. brasiliensis) on different casing layers and environments. World J Microbiol Biotechnol. 2010;26:1857-63.

26. Zied DC, Nunes JS, Nicolini VF, Pardo-Giménez A, Rinker DL, Dias ES. Tolerance to Lecanicillium fungicola and yield of Agaricus bisporus strains used in Brazil. Sci Hortic. 2015;190:117-22 